Apidologie, 1987, 18 (2), 121-128

\title{
EFFICACY OF KETONES ON THE FORAGING BEHAVIOUR OF APIS FLOREA F. IN FIELD CONDITIONS
}

\author{
Mahavir GUPTA \\ Laboratory of Animal Behaviour and Simulated Ecology \\ Department of Zoology \\ Haryana Agricultural University \\ Hisar-125004 Haryana India
}

\begin{abstract}
SUMMARY
Three ketones (methyl propyl ketone, benzyl methyl ketone and methyl pentyl ketone) were tested on onion (Allium cepa) and three (methyl pentyl ketone, ethyl propyl ketone and ethyl pentyl ketone) were screened on carrot (Daucus carota) under field conditions for their repellent action against Apis florea $\mathrm{F}$. The number of bees visiting the control and treated crop plants was recorded. The effect of repellents decreased with the passage of time (Figs 1-6). Field experiments clearly demonstrated that the duration of stability of ketones is greater on $D$. carota than on $A$. cepa. Clearly, temperature is the main influential factor in the determination of repellent effect; relative humidity acts as a balancing factor (Table 1).
\end{abstract}

\section{INTRODUCTION}

Mass scale mortality of honey bees due to the wide spread use of insecticides affects the pollination of agricultural crops (ShAw, 1941 ; STUTE, 1957 ; Anderson and AtKins, 1958 ; Palmer-Jones, 1958 ; Beya et al., 1959 ; Chamberlain, 1959 ; King, 1959 ; Wafa et al., 1960 ; Morse, 1964 ; JohanSEN, 1977 ; MAYER et al., 1980 ; GuPTA, 1982 ; SANFORD, 1983 ; GuPTA, $1986 \mathrm{a}, \mathrm{b})$. The importance of bee poisoning has increased with greater use of insecticides and other chemicals in India during the last twenty years. Indiscriminate use of pesticides has been a potential danger to the ecological system including the survival of bees.

Various chemicals exhibited a repellent effect in low concentration in the laboratory but none was found to be of practical use in the field. Protection of bees can be obtained through the use of a repellent individually or in combination with pesticides (BhardwaJ, 1974 ; KumarI, 1976 ; Goyal, 1977 ; 
GuPTA, 1982, 1983; GuPTA and KAPIL, 1984; GuPTA, 1985 ; GupTA, $1986 \mathrm{a}, \mathrm{b}$ ). The effect of a repellent is dependent upon several physical and biological factors. Some of these factors change in a short space of time. Therefore, studies of repellents need careful standardization before good results can be expected. The present investigations are based on the above ideas.

\section{MATERIALS AND METHODS}

A total of 131 compounds have been screened in this laboratory (GUPTA, 1982, 1983; GUPTA and KAPIL, 1984 ; GUPTA, 1985 ; GUPTA, $1986 \mathrm{a}$, b) and only 6 ketones were screened under field conditions against Apis florea F. Three ketones (methyl propyl ketone, benzyl methyl ketone and methyl pentyl ketone) were tested on onion (Allium cepa) and three (methyl pentyl ketone, ethyl propyl ketone and ethyl pentyl ketone) were tested on carrot (Daucus carota) at $1 \%$ concentration.

Eight plots of one $\mathrm{m}^{2}$ size, each separated from the next by five meters, were marked on the crop area. Four of these plots (test) were sprayed with chemical water solution (CW) using a one liter capacity hand spray pump. The other four plots (control) were sprayed with the same quantity of distilled water (DW). The number of bees visiting the categories of plots was counted for 5 min alternately. Thus, 6-7 countings of each plot per day were recorded. The percent repellency was calculated by using the following formula :

$$
100-\frac{\text { Number of bees on } \mathrm{CW}}{\text { Number of bees on } \mathrm{CW}+\mathrm{DW}} \times 100
$$

Temperature, relative humidity and solar radiation were recorded before and after each set of observations.

\section{RESULTS AND DISCUSSION}

The effect of repellents decreased sequentially with the passage of time (Figs 1-6) and the relationships were linear and negatively significant. The effectiveness of various ketones was observed in the following order : methyl pentyl ketone $(D$. carota $)=$ ethyl propyl ketone $(D$. carota $)=$ ethyl pentyl ketone (D. carota) $360 \mathrm{~min}>$ benzyl methyl ketone (A. cepa) $240 \mathrm{~min}$ $>$ methyl propyl ketone $(A$. cepa) $=$ methyl pentyl ketone $(A$. cepa) $60 \mathrm{~min}$. Thus the stability of the ketones was greater on $D$. carota than on $A$. cepa. The slopes obtained from the functional linearity are indicative of this conclusion. This means that the effect of ketones varies with the crop. Moreover, the duration of effectiveness of each repellent is also variable. This conforms with similar results obtained by PALMer et al., 1959 ; ANDERSON et al., 1960 ; GUPTA, 1982 ; GUPTA and KAPIL, 1984 ; and GUPTA, 1985. Similar results have also been obtained in mosquitoes with different repellents (KHAN et al., 1975). 


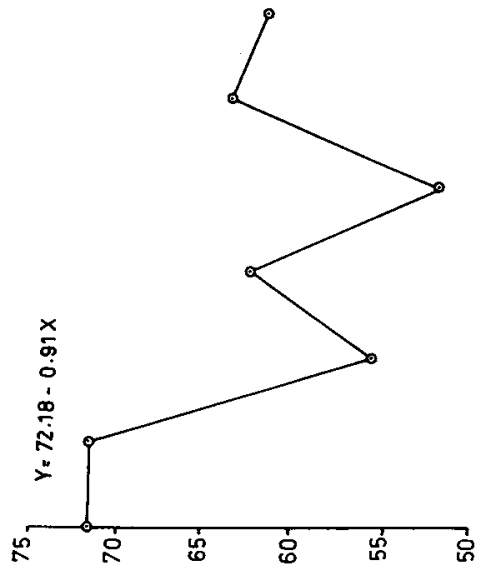

(\%) Nouallacad

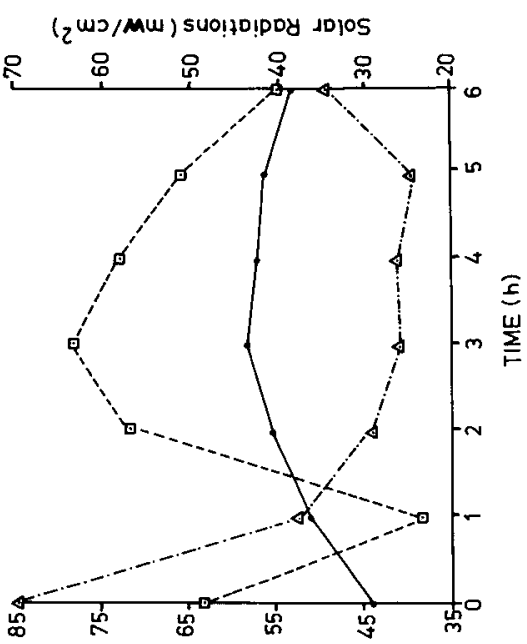

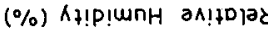

(כ.) a.njo.adwa1
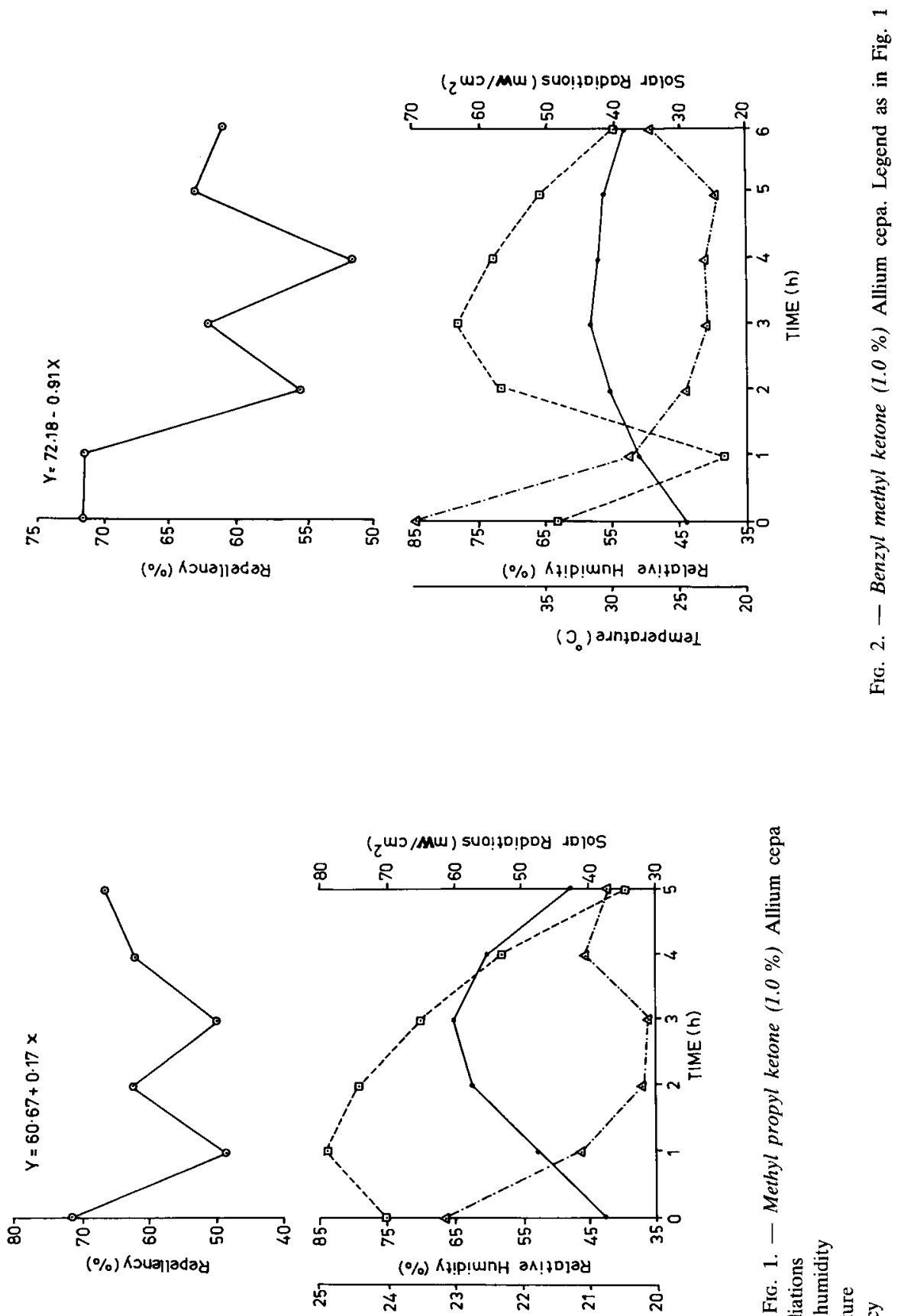

(כ. ) asnjojadmal

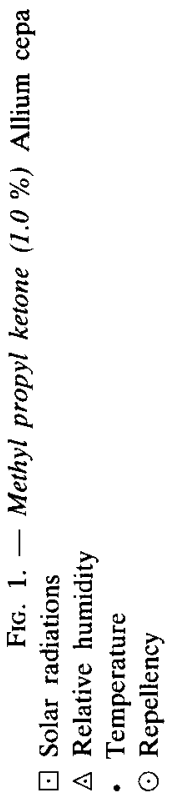




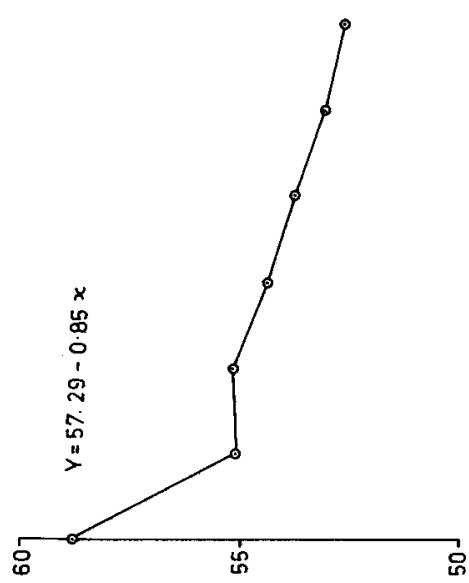

(\%) Koualjaday

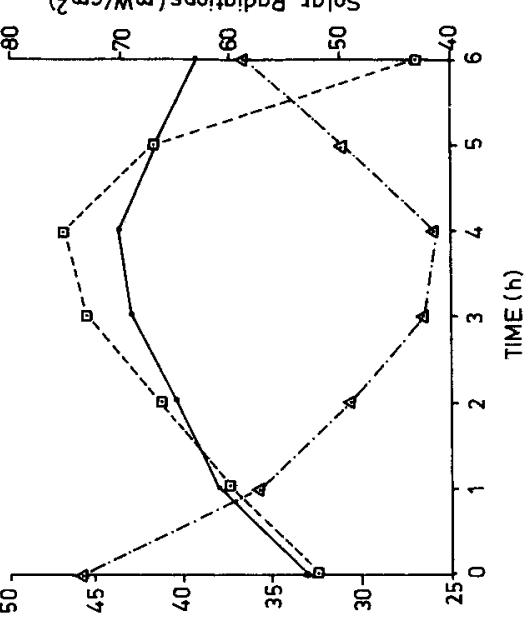

(\%) Kt!p!wnh an!łojay $\stackrel{n}{m}$

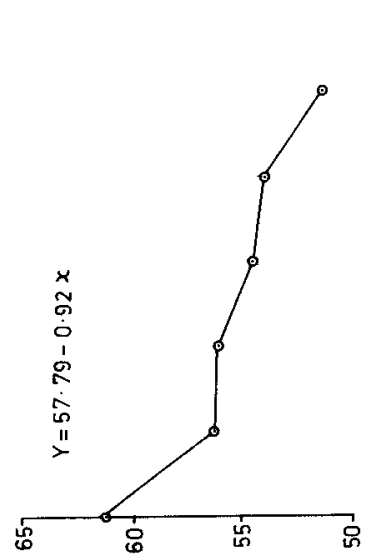

$(\%)$ Noualladay

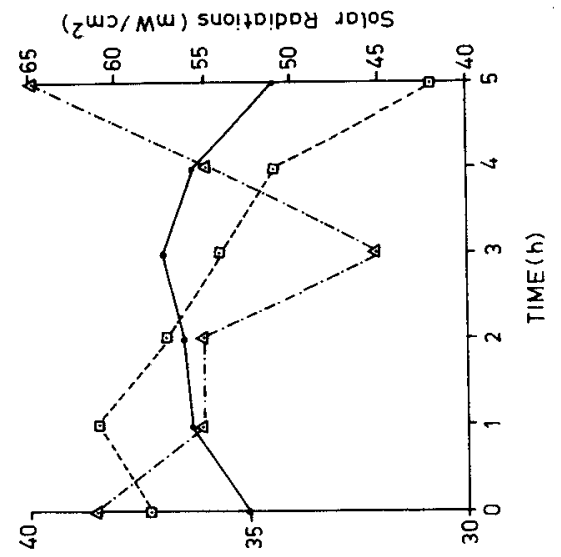

$(\%)$ K!!P!UnH an!lDIay

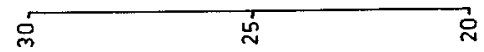

(3.) a.nionadwal 

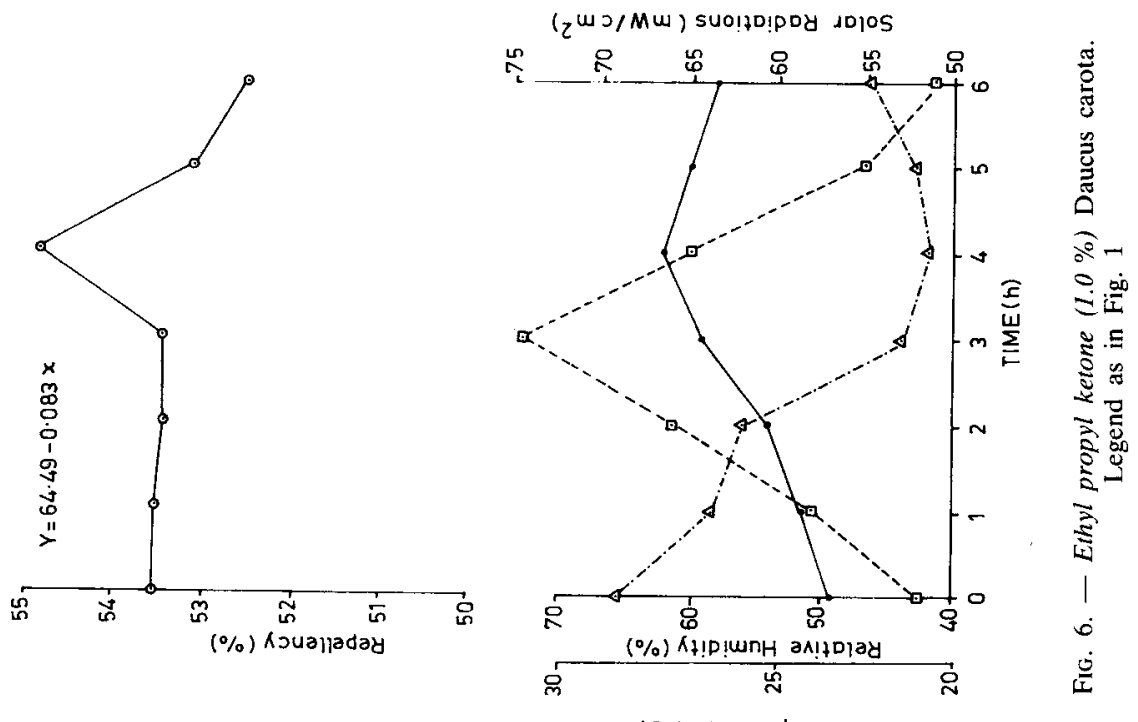

(כ) adniosaduas
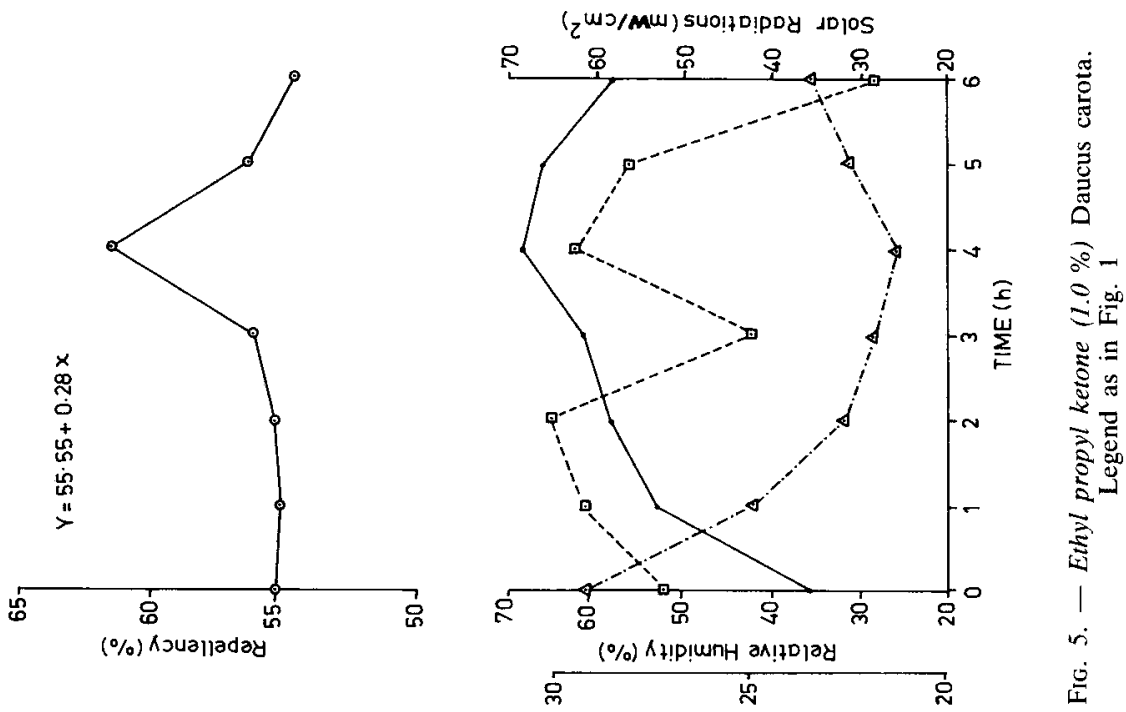

(כ) )adnqdadual 


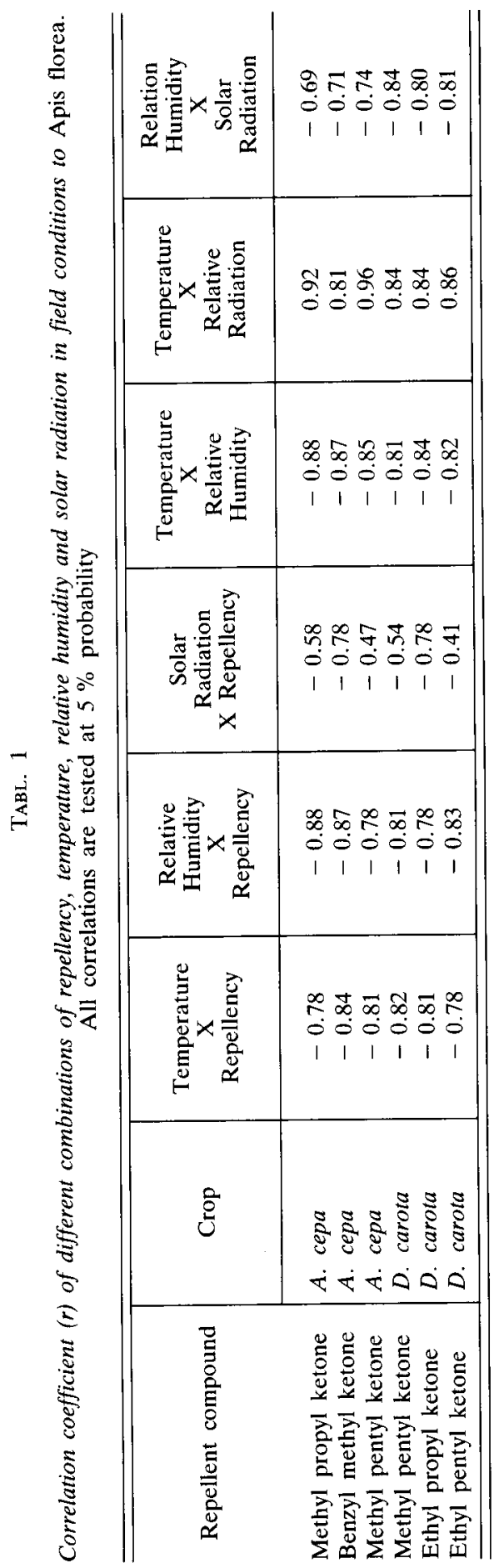


Solar radiation, temperature and relative humidity were recorded after every minute to make comparison of the various observations taken sequentially (Figs 1-6). The statistical analysis of the data indicate a significant relationship between temperature and solar radiation, temperature and repellency, temperature and relative humidity. However, the relationships between relative humidity and repellency, solar radiation and humidity were not consistently significant (Table 1). Clearly, temperature is the main influential factor in determination of repellent effect. The coefficient of correlation of repellency with temperature is negative. This supports the idea that solar radiation is a supportive factor and relative humidity with positive non significant correlation appears to work as a balancing factor.

It was concluded that the duration of effectiveness of ketones was greater on $D$. carota than on $A$. cepa.

Received for publication in April 1986. Accepted for publication in October 1986.

\section{ACKNOWLEDGEMENTS}

I am thankful to Prof. R.P. KaPIL for providing the field facilities. Thanks are due to Dr. S.K. GarG for helpful discussion and to Sh. R.S. MoHLA, Research Scholar for many insightful suggestions and help in field studies. The assistance of Sh. Dalbir Singh in field experiments is also acknowledged.

\section{RÉSUMÉ}

\section{ACTION DES CÉTONES SUR LE COMPORTEMENT DE BUTINAGE D'APIS FLOREA F. DANS LES CONDITIONS NATURELLES}

On a testé l'action répulsive, vis-à-vis d'Apis florea, de 3 cétones (méthyl propyl cétone, benzyl méthyl cétone et méthyl pentyl cétone) sur l'oignon (Allium cepa L.) et 3 autres (méthyl pentyl cétone, éthyl propyl cétone et éthyl pentyl cétone) sur la carotte (Daucus carota) en conditions naturelles. On a enregistré le nombre d'abeilles sur le témoin et sur les plantes traitées. L'effet répulsif décroît avec le temps (Fig. 1 à 6). Les expériences en champ montrent clairement que les cétones sont plus stables sur $D$. carota que sur $A$. cepa. La température est le principal facteur qui détermine la répulsivité; l'humidité relative agit comme facteur d'équilibre (Tabl. 1).

\section{ZUSAMMENFASSUNG}

\section{AUSWIRKUNG VON KETONEN AUF DAS SAMMELVERHALTEN DER ASIATISCHEN HONIGBIENE APIS FLOREA F. BEI FELDBEDINGUNGEN}

Drei verschiedene Ketone - Methylpropylketon, Benzylmethylketon und Methylpentylketon wurden auf Zwiebelpflanzen (Allium cepa) und drei andere Ketone - Methylpentylketon, Äthylpropylketon und Äthylpentylketon - auf Karottenpflanzen (Daucus carota) unter Feldbedingungen daraufhin getestet, ob sie eine Repellentwirkung auf die asiatische Honigbiene Apis florea zeigen. Die Anzahl der Bienen, die die Kontrollpflanzen und die behandelten Pflanzen besuchten, wurde protokolliert. Der 
Repellenteffekt verschwand mit der Zeit (Abb. 1-6). Die Feldexperimente zeigten, daß die Stabilität der Ketone auf $D$. carota länger andauerte als auf $A$. cepa. Die Temperatur stellt den hauptsächlichen Einflußfaktor für die Bestimmung eines Repellenteffekts dar und die relative Feuchte agiert als ausgleichender Faktor (Tab. 1).

\section{REFERENCES}

Anderson L.D. and AtKins E.L. Jr., 1958. - Toxicity of pesticides to honey bees in laboratory and field tests. J. Econ. Entomol., 51, 103-108.

Anderson L.D., Atkins E.L. Jr., Todo F. and McGregor S.E., 1960. — Field tests on the effect of pesticides on honey bees in alfalfa bloom. Univ. Calif. Citrus Exp. Sta. Rep. Proj., 152-175.

Beye F., KaEser W. und Buchner R., 1959. - Zur Wirkung von Aktivsubstanzen verchiedener Insektizide auf Bienen. Anz. Schädlingskd., 32, 41-43, 121-123.

Bhardwas S.C., 1974. - Evaluation of some chemicals as repellents to Apis florea F. Ph.D. Thesis, Haryana Agric. Univ., Hissar (India), 125 p.

ChamberLain W.F.S., 1959. - The behavior of agricultural insects towards olfactory repellents in olfactometer. J. Econ. Entomol., 52, 286-289.

Goval K., 1977. - Olfacto-gustatory response of Apis florea F. to some ketones. M.Sc. Thesis, Haryana Agric. Univ. Hisar, Indian, pp. 64.

Gupta M., 1982. - Olfactory physiology of Apis florea F. with reference to repellents. Ph.D. Thesis, Haryana Agric. Univ., Hisar, India, pp. 168.

GuPta M., 1983. - Honey bees : Pesticidal hazards. Haryana Review, 17, 19.

GupTA M., 1985. - Olfactory response of Apis florea F. to some compounds of essential oils. Proc. 72nd Indian Science Congress, A 267, Lucknow.

Gupta M., 1986 a. - Screening of honey bee repellents. Proc. 73rd Indian Science Congress, Delhi (in press).

GuPTA M., 1986 b. - Behaviour of Apis florea F. towards olfactory repellents in olfactometer. Proc. $73 r d$ Indian Science Congress, Delhi (in press).

GuPTA M. and KaPIL R.P., 1984. - Olfactory response of workers of Apis florea F. to some repellents in semi-field conditions. Proc. 5th Intern. Symp. Pollin., Versailles, 65-78.

Johansen C.A., 1977. - Pesticides and Pollinators. Annu. Rev. Entomol., 22, 177-191.

Khan A.A., Maibach H.I. and Skidamore D.L., 1975. - Addition of perfume fixative to mosquito repellents to increase protection time. Mosquito News, 35, 23-26.

King C.C., 1959. - The effect of fungicides. Glean. Bee Cult., 87, 678-681.

Kumari R., 1976. - Olfacto-gustatory response of Apis florea F. to some compounds of essential oils. M.Sc. Thesis, Haryana Agric. Univ., Hisar, India, pp. 54.

MaYer D.F., Johansen C.A., Eves J.D., Britt R. and Bergin D., 1980. - Monitoring of honey bee mortality from insecticides. Am. Bee J., 120, 352-355.

Morse R.A., 1964. - Bee repellents. Am. Bee J., 104, 93-94.

Palmer-Jones T., 1958. - Laboratory methods for measuring the toxicy of pesticides to honey bees. N.Z.J. Agric. Res., 1, 290-300.

Palmer-Jones T., Foster I.W. and Jeffery G.L., 1959. - Effect on honey bees of rogor and endothion applied from the air as spray to Brassica trials of M.G.K. repellent 874. N.Z.J. Agric. Res., 2, 475480.

SANFord M.T., 1983. - Protecting honey bees from pesticides. Ext. Ser. Univ. of Florida, No. 534, pp. 15.

SHAW F.R., 1941. - Bee poisoning review of more important literature. J. Econ. Entomol., 34, 16-21.

Stute K., 1957. - Bisherige Ergebnisse von Versuchen mit « repellents» bei der Honigbiene. Anz. Schädlingskd., 30 (3), 38-43.

Wafa A.K., Nahal. A.K. and Ahmed S.M., 1960. - Effect of some insecticides on honey bees. Elfelsha, pp. 4. 